\title{
Kevin P. Spicer, Ed. and Martina Cucchiara, Trans. The Evil that Surrounds Us: The WWII Memoir of Erna Becker-Kohen
}

(Bloomington: Indiana University Press, 2017), viii + 174 pp.

\author{
MARTIN MENKE \\ mmenke@ rivier.edu \\ Rivier University, Nashua, NH 03060
}

This slender, accessible volume - a diary with an introduction and annotation by the editors / translators - is a rich contribution to the literature and scholarship on the relationship between German Catholics and German Jews during World War II. For many years, scholarly interest has focused on the actions or inaction of bishops and other leaders of the Church. Further, much of the Shoah survivor literature has focused on individuals who went underground in Berlin or in occupied territories in Western and Eastern Europe. This important diary provides evidence of the relationship of lay German Catholics from modest backgrounds and of clergy largely at the parish level with a Jewish woman, Erna Becker-Kohen, who was married to a Catholic, Gustav Becker, and who herself converted to Catholicism in 1936.

Erna's diary covers the years from 1937 to 1963 . She writes that after 1933, she, Gustav, and their son Silvan face discrimination, though as a Jewish-Christian couple their treatment was comparatively milder than that faced by Jews not in mixed marriages. Once the war begins in 1939, however, the family suffers increasing restrictions, especially Erna (who despite converting is still considered a Jew by the Nazis). She loses ration coupons and other benefits to which gentile Christians are entitled. While she is not required to wear the yellow star, this exemption is increasingly less helpful as discrimination and persecution of Jews becomes more common at the grass-roots level. The Becker family, however, feels the pain of discrimination most when trying to find a vacation spot in Nazi-ruled Germany that will not take as guests members of a mixed marriage. The family seeks a place in which to find normalcy, if only for a short time. 
In Berlin and in Frankfurt, the home of her mother, Erna finds Catholics and especially Catholic clergy willing to provide her, a Jew who converted to Catholicism, with counsel and guidance. Others, however, including secular clergy, monks, and sisters, are too imbued with religious or racial antisemitism to see her as a vulnerable Christian with a young son. In a convent in Berlin-Schlachtensee, a sister has her and her son ejected because she refuses to live under the same roof as these Jews. Arrested in her apartment, Erna manages to argue her way out of the Fabrikaktion in Berlin that gave rise to the Rosenstrasse protest. Subsequently Gustav and Erna decide that Erna and Silvan need to leave Berlin. They make their way to Austrian Tyrol, where they hope to find shelter in small mountain villages.

Without legal papers, without any right to food rations, to health care, or to the housing entitlements provided to evacuees from Allied air raids, Erna and Silvan must find individuals who are willing to shelter them. The bishop of Innsbruck and other clergy support Erna. They prepare her for confirmation and help her find shelter. Despite the bishop's efforts, however, some of the Catholic institutions and private homes at which they call refuse to help them. Erna and Silvan experience the full spectrum of Catholic responses. Some Christians were willing to risk their own lives, to share their own meagre rations, and to provide shelter even in the most cramped quarters without any consideration of recompense. Other Catholics provide them with adequate shelter but also seek to profit from doing so. Some extort what they can from the persecuted without showing any real concern for their welfare. Some who initially helped them soon lose their courage and ask Erna and Silvan to move on after a day or two. After all, those caught sheltering Jews risk a death sentence or removal to a concentration camp. The spectrum of Catholic actions (or inactions) for persecuted Jews is wide.

Spicer and Cucchiara also demonstrate Erna's struggles with her Catholic faith. Although there is no evidence Erna converted out of expediency, she often questions her faith and seeks reassurance from clergy and from lay Catholics. She seeks to discuss her doubts with individuals who could help her to dispel them while respecting the authenticity of her quandaries. In the edited diary, it seems she does not encounter anyone who dismissed her questions as unimportant or irrelevant. In practice, Erna is demonstratively Catholic. In several places where she finds shelter with Silvan, she organizes Marian devotions and other celebrations for children. She even risks detection by engaging local children to prepare these events with music and flowers.

Erna expresses no hostility or ill-will toward family members and others who remained Jewish. She misses those who emigrated successfully and mourns those who perished in the Shoah. Facing one hardship after another, Erna eventually learns her husband has been sent to a labor camp near Halle for refusing to renounce his wife and child. She enlists a relative in Switzerland to provide material relief to her husband. In the end, all three survive the war, although Gustav's health is damaged beyond repair and he must spend two years in bed recovering from musculoskeletal injuries which shorten his life. 
While evidently a faithful Catholic, in her diary Erna often bitterly complains about those, especially Catholics, who refused to help her. Perhaps understandably, she seems to lack an appreciation of the risks taken by those who might help her. Similarly, in post-war entries, she expresses great bitterness toward those who remained supporters of Nazism.

Spicer and Cucchiara preface this edited diary with an excellent introduction. They alert the reader to the challenges of understanding Catholic-Jewish relations during the Nazi era, to the complexities of Nazi persecution of those it considers Jews, and to the diverse expressions of Christian faith in this period. They also engage scholarly debates about persecution and rescue of Jews in an even-handed way. Their fluid, clear, and readable translation assists the reader in understanding Erna's story. A gripping volume, it will be of interest to a popular audience and is suitable for undergraduates. It will also be valuable to scholars for highlighting the complexity of Christian identity and of Jewish-Christian relations during the Shoah. 